\title{
Virulence and Evolution of West Nile Virus, Australia, 1960-2012
}

\author{
Natalie A. Prow, ${ }^{1,2}$ Judith H. Edmonds, ${ }^{2}$ David T. Williams, Yin X. Setoh, Helle Bielefeldt-Ohmann, \\ Willy W. Suen, Jody Hobson-Peters, Andrew F. van den Hurk, Alyssa T. Pyke, Sonja Hall-Mendelin, \\ Judith A. Northill, Cheryl A. Johansen, David Warrilow, Jianning Wang, Peter D. Kirkland, \\ Stephen Doggett, Christy C. Andrade, ${ }^{3}$ Aaron C. Brault, Alexander A. Khromykh, ${ }^{4}$ Roy A. Hall ${ }^{4}$
}

Worldwide, West Nile virus (WNV) causes encephalitis in humans, horses, and birds. The Kunjin strain of WNV $\left(\mathrm{WNV}_{\text {KUN }}\right)$ is endemic to northern Australia, but infections are usually asymptomatic. In 2011, an unprecedented outbreak of equine encephalitis occurred in southeastern Australia; most of the $\approx 900$ reported cases were attributed to a newly emerged $W_{N V_{\text {KUN }}}$ strain. To investigate the origins of this virus, we performed genetic analysis and in vitro and in vivo studies of $13 \mathrm{WNV}_{\mathrm{KUN}}$ isolates collected from different regions of Australia during 19602012. Although no disease was recorded for 1984, 2000, or 2012, isolates collected during those years (from Victoria, Queensland, and New South Wales, respectively) exhibited levels of virulence in mice similar to that of the 2011 outbreak strain. Thus, virulent strains of $\mathrm{WNV}_{\text {KUN }}$ have circulated in Australia for $\geq 30$ years, and the first extensive outbreak of equine disease in Australia probably resulted from a combination of specific ecologic and epidemiologic conditions.

$\mathrm{W}$ est Nile virus (WNV) is a mosquito-transmitted flavivirus that causes encephalitis. Outbreaks of

Author affiliations: The University of Queensland, St. Lucia, Queensland, Australia (N.A. Prow, J.H. Edmonds, Y.X. Setoh, H. Bielefeldt-Ohmann, W.W. Suen, J. Hobson-Peters,

A.A. Khromykh, R.A. Hall); CSIRO Australian Animal Health Laboratory, Geelong, Victoria, Australia (D.T. Williams, J. Wang); The University of Queensland, Gatton, Queensland, Australia (H. Bielefeldt-Ohmann, W.W. Suen); Department of Health, Brisbane, Queensland, Australia (A.F. van den Hurk, A.T. Pyke, S. Hall-Mendelin, J.A. Northill, D. Warrilow); The University of Western Australia, Nedlands, Western Australia, Australia (C.A. Johansen); Elizabeth Macarthur Agriculture Institute, Menangle, New South Wales, Australia (P.D. Kirkland); University of Sydney and Pathology West-ICPMR, Westmead, New South Wales, Australia (S. Doggett); University of California, Davis, California, USA (C.C. Andrade, A.C. Brault); Centers for Disease Control and Prevention, Fort Collins, Colorado, USA

(C.C. Andrade, A.C. Brault)

DOI: http://dx.doi.org/10.3201/eid2208.151719 potentially fatal neurologic syndromes have occurred in Europe and Africa (1); recently, however, strains of WNV have caused large outbreaks of encephalitis in humans and horses in the Americas and Australia $(2,3)$. The Kunjin strain of $\mathrm{WNV}\left(\mathrm{WNV}_{\mathrm{KUN}}\right)$ is indigenous to Australia and historically has caused only relatively mild, nonfatal disease in humans and horses. However, in 2011, a large unprecedented outbreak of encephalitis in horses, involving $\approx 900$ reported cases, occurred in southeastern Australia; a high proportion of cases were attributed to the emergence of a virulent strain of $\mathrm{WNV}_{\mathrm{KUN}}(3,4)$. $\mathrm{WNV}_{\mathrm{KUN}}$ has been shown to be enzootic to northern Australia and to have episodic activity in southern regions thought to be associated with periods of heavy rainfall (5). However, the epidemiology of $\mathrm{WNV}_{\mathrm{KUN}}$ seems to have changed over the past decade; virus activity has been detected in the absence of prior flooding and in areas where it was previously not detected (4).

Studies comparing the virulence of various WNV strains in mouse models have identified several motifs, residing in both structural and nonstructural genes as well as in the $5^{\prime}$ and $3^{\prime}$ untranslated regions (UTRs). These motifs were associated with enhanced viral invasion of the central nervous system and onset of neurologic disease $(5-11)$.

To identify potential markers of virulence of $\mathrm{WNV}_{\mathrm{KUN}}$ in Australia, we investigated evolutionary mechanisms behind the emergence of virulent strain(s) by using established mouse models to compare the neuroinvasive properties of $\mathrm{WNV}_{\mathrm{KUN}}$ isolates collected from different regions of Australia during 1960-2012. To investigate known markers of WNV virulence, we conducted comparative analyses of viral genome sequences.

\footnotetext{
${ }^{1}$ Current affiliation: QIMR Berghofer Medical Research Institute, Herston, Queensland, Australia.

${ }^{2}$ These authors contributed equally to the major technical aspects of the work.

${ }^{3}$ Current affiliation: Willamette University, Salem, Oregon, USA.

${ }^{4}$ These authors served as joint senior authors.
} 


\section{Methods}

\section{Cell Culture, Virus Production, and Titration}

We used $13 \mathrm{WNV}_{\mathrm{KUN}}$ strains isolated during 1960-2012 (Table 1) and African green monkey kidney (Vero) and Aedes albopictus mosquito (C6/36) cells, cultured as previously described (3). The 1960 prototype $\mathrm{WNV}_{\mathrm{KUN}}$ strain $\left(\mathrm{WNV}_{\mathrm{KUN} 1960}\right)$ was used as the attenuated reference virus and was either an unknown passage of the original isolate $\left(\mathrm{WNV}_{\mathrm{MRM16}}\right)$ or derived from an infectious clone of a plaque-purified virus $\left(\mathrm{WNV}_{\mathrm{MRM61C}}\right)(12,13)$. These isolates were previously shown to be phenotypically identical $(13,14)$. WNV strain NY99-4132 was obtained from the US Centers for Disease Control and Prevention (Fort Collins, CO, USA) and used as a virulent control. Virus stocks and methods for determination of infectious titers have been described (3).

\section{Antigenic Analysis}

We compared reactivity of $\mathrm{WNV}_{\mathrm{KUN}}$ isolates with a panel of monoclonal antibodies (mAbs) with that of reference strains $\mathrm{WNV}_{\text {KUN1960 }}$ and $\mathrm{WNV}_{\mathrm{NY99}}$. To do so, we used a fixed-cell ELISA, as previously described $(3,5,15)$.

\section{Virus Replication Kinetics}

We performed growth kinetics analysis by infecting Vero and $\mathrm{C} 6 / 36$ cells at a multiplicity of infection of 1 at $37^{\circ} \mathrm{C}$ (Vero) or $28^{\circ} \mathrm{C}(\mathrm{C} 6 / 36)$ with $\mathrm{WNV}_{\mathrm{KUN}}$. Culture supernatants were harvested at $0,24,48$, and $72 \mathrm{~h}$ after infection (Vero) and 0, 24, 48, 72, 96, and $120 \mathrm{~h}$ after infection (C6/36) and titrated (3). Statistical significance from 3 independent experiments was determined by using 2-way analysis of variance following $\log$ transformation (16). Mean virus titers were compared between viruses by using the Tukey method for pairwise multiple comparisons (GraphPad Prism, version 6.0; GraphPad Software Inc., San Diego, CA, USA).

\section{Virulence in Mice}

Performance of all animal procedures was approved by The University of Queensland Animal Ethics Committee. To determine virus virulence in mice, we intraperitoneally inoculated 20 Swiss white outbred CD-1 mice (weanlings [18-19 days of age] and young adults [28 days of age]) with a range of doses $(0.1-10,000 \mathrm{PFU})$ of each WNV strain (Table 1) (3). The significance of clinical differences between groups was calculated by Kaplan-Meier analysis and analyzed by log-rank test where noted (GraphPad Prism, version 6.0). A virus strain was designated as virulent if survival times for mice infected with this strain (both age groups) differed significantly from those of mice infected with the attenuated reference strain $\mathrm{WNV}_{\mathrm{KUN} 1960}$. All virus strains that did not meet this criterion for virulence were designated as attenuated.

\section{Full-length Genome Sequencing}

We sequenced $9 \mathrm{WNV}_{\mathrm{KUN}}$ genomes (online Technical Appendix Table 1, http://wwwnc.cdc.gov/EID/ article/22/8/15-1719-Techapp1.pdf) by using random primer sequencing on extracts of C6/36 cell cultures (17). Viral RNA was extracted by using a MagMAX-96 Viral RNA Isolation Kit (Ambion, Waltham, MA, USA) according to the manufacturer's instructions. cDNA synthesis and random PCR amplification were conducted according to previously described methods (18), and resultant PCR amplicons were used for sequencing library preparation. DNA libraries were prepared by using a Nextera XT DNA Sample Preparation Kit (Illumina, San Diego, CA, USA) according to the manufacturer's protocols. Paired-end sequencing of 150-bp fragments was performed by using a MiSeq Reagent Kit V2 (300 cycles) and MiSeq Sequencing System (Illumina). Sequencing data were analyzed by using CLC Genomics Workbench version 6.5.0 (http:// www.clcbio.com). The sequence data were trimmed by

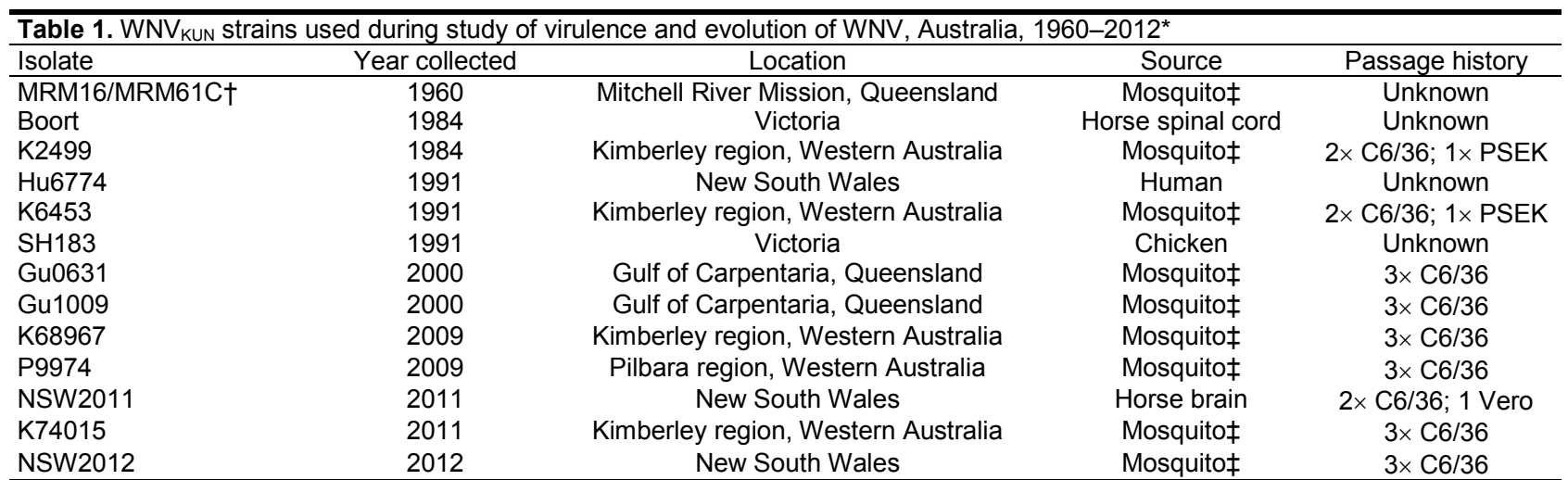

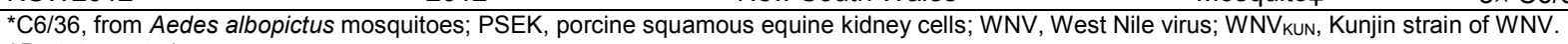


using quality scores specified in CLC Genomics Workbench before performing read-mapping analysis. The genome sequences were assembled by read mapping against the reference $\mathrm{WNV}_{\mathrm{KUN}}$ strain genome (GenBank accession no. JX276662) with use of default parameters in the mapping algorithm. Where gaps in the genome sequence or low coverage $(<10$ reads/site) were observed, conventional Sanger sequencing was performed to complete or verify the sequence. Oligonucleotide primers sequences designed for these purposes are available upon request to A.A.K or R.A.H.

\section{Bioinformatics Analysis}

We used MUSCLE, as implemented in MEGA6 (19), to align complete open reading frame (ORF) $(10,320 \mathrm{nt})$ and partial (402 nt) envelope (E) gene nucleotide sequences of the newly sequenced $\mathrm{WNV}_{\mathrm{KUN}}$ strains, together with those available for 6 other $\mathrm{WNV}_{\mathrm{KUN}}$ strains and selected WNV isolates, representing different lineages. We estimated maximum-likelihood phylogenetic trees by using PhyML version 3.0 (20) and by using substitution models and rates among sites selected with JModelTest version 2.1.5 (21). We tested reliability of the inferred trees by using the bootstrap method with 1,000 replicates. All trees were rooted with analogous ORF sequences from Murray Valley encephalitis virus (GenBank accession no. NC000943) and Japanese encephalitis virus (GenBank accession no. EF571853) and visualized by using FigTree version 1.4.0 (http://tree.bio.ed.ac.uk/software/ figtree/). Pairwise distances were determined at the nucleotide and amino acid levels by using the p-distance model in MEGA6.

\section{Results}

\section{WNV $_{\text {KuN }}$ Strains}

A panel of previously characterized mAbs $(5,15,22-$ 24) was used to antigenically type $13 \mathrm{WNV}_{\mathrm{KUN}}$ strains. The binding profiles of these mAbs confirmed that all $\mathrm{WNV}_{\mathrm{KUN}}$ isolates closely resembled the prototype $\mathrm{WNV}_{\text {KUN1960 }}$ strain, including strong recognition by $\mathrm{mAb}$ $10 \mathrm{~A} 1$, known to be specific for $\mathrm{WNV}_{\mathrm{KUN}}$ strains (Table 2) $(2,24)$. Only $\mathrm{WNV}_{\mathrm{KUN}}$ strains isolated before 2000 were recognized by $\mathrm{mAb} 5 \mathrm{H} 1$, which binds a linear epitope in the $\alpha \mathrm{A} 3$ motif (residues 39-53) in the methyltransferase domain of nonstructural (NS) protein 5 (15). Lack of 5H1 binding was associated with a substitution at residue 49 (Ile-Val) in $\alpha \mathrm{A} 3$ (Table 3); this finding was consistent with previous mutagenesis study findings that a substitution of Ile to Ala at this residue was associated with abolition of 5H1 binding (26).

\section{Glycosylated E Proteins}

All analyzed $\mathrm{WNV}_{\mathrm{KUN}}$ isolates collected after 1960 contain glycosylated $\mathrm{E}$ proteins. The sequence analysis of the $\mathrm{E}$ gene of $\mathrm{WNV}_{\mathrm{KUN}}$ isolates revealed the presence of a conserved potential N-linked glycosylation site at residue 154 in all but the prototype $\mathrm{WNV}_{\mathrm{KUN} 1960}$ isolate (Table 3). To confirm that this site was indeed glycosylated on the viral E protein, each virus was assessed for recognition in ELISA by mAbs 17D7 and 3.101C (Table 2), which specifically recognize glycosylated and unglycosylated $\mathrm{WNV}_{\mathrm{KUN}}$ E proteins, respectively $(5,23)$. The results supported the predictions from our sequencing data; all $\mathrm{WNV}_{\mathrm{KUN}}$ strains except the prototype $\mathrm{WNV}_{\mathrm{KUN} 1960}$ strain were recognized by mAb 17D7 but not by 3.101C.

\begin{tabular}{|c|c|c|c|c|c|c|c|c|c|}
\hline \multirow[b]{3}{*}{ Strain } & \multirow[b]{3}{*}{$\begin{array}{l}\text { Year of } \\
\text { isolation }\end{array}$} & \multicolumn{8}{|c|}{ Monoclonal antibodies, by specificity } \\
\hline & & \multirow[b]{2}{*}{$\begin{array}{l}\text { Panflavivirus, } \\
\text { 4G2, anti-env }\end{array}$} & \multirow{2}{*}{$\begin{array}{l}\text { Pan-WNV, } \\
\text { 2B2, anti- } \\
\text { env }\end{array}$} & \multicolumn{3}{|c|}{ WNV KUN-specific } & \multirow[b]{2}{*}{$\begin{array}{c}\text { Glycosylated } \\
\text { E, 17D7 }\end{array}$} & \multirow[b]{2}{*}{$\begin{array}{c}\text { Unglycosylated } \\
E, 3.101 \mathrm{C}\end{array}$} & \multirow{2}{*}{$\begin{array}{l}\text { MVEV- } \\
\text { specific, } \\
10 C 6\end{array}$} \\
\hline & & & & $\begin{array}{c}\text { 10A1, } \\
\text { anti-env }\end{array}$ & $\begin{array}{l}\text { 5D4, anti- } \\
\text { NS5 }\end{array}$ & $\begin{array}{c}5 \mathrm{H} 1 \\
\text { anti-NS5 }\end{array}$ & & & \\
\hline \multicolumn{10}{|l|}{ WNV } \\
\hline KUN1960 & 1960 & + & + & + & + & + & - & + & - \\
\hline Boort & 1984 & + & + & + & + & + & + & - & - \\
\hline K2499 & 1984 & + & + & + & + & + & + & - & - \\
\hline SH183 & 1991 & + & + & + & + & + & + & - & - \\
\hline K6453 & 1991 & + & + & + & + & + & + & - & - \\
\hline Hu6774 & 1991 & + & + & + & + & + & + & - & - \\
\hline Gu0631 & 2000 & + & + & + & + & + & + & - & - \\
\hline Gu1009 & 2000 & + & + & + & + & + & + & - & - \\
\hline K68967 & 2009 & + & + & + & + & - & + & - & - \\
\hline P9974 & 2009 & + & + & + & + & - & + & - & - \\
\hline NSW2011 & 2011 & + & + & + & + & - & + & - & - \\
\hline K74015 & 2011 & + & + & + & + & - & + & - & - \\
\hline NSW2012 & 2012 & + & + & + & + & - & + & - & - \\
\hline \multicolumn{10}{|l|}{ Reference } \\
\hline$W_{N} V_{N Y 99}$ & 1999 & + & + & - & + & - & + & - & - \\
\hline MVEV $_{1-51}$ & 1951 & + & - & - & - & - & - & - & + \\
\hline
\end{tabular}


Table 3. Amino acid sequences in the West Nile virus genome*

\begin{tabular}{|c|c|c|c|c|c|c|c|}
\hline \multirow[b]{2}{*}{ WNV strain } & \multirow[b]{2}{*}{$\begin{array}{l}\text { Year of } \\
\text { isolation }\end{array}$} & \multirow[b]{2}{*}{$\begin{array}{c}\text { prM, residue } \\
22 / 72 \dagger\end{array}$} & \multicolumn{3}{|c|}{ Putative virulence determinant } & \multirow[b]{2}{*}{$\begin{array}{l}\text { NS5, } \\
\text { residue } 49\end{array}$} & \multirow[b]{2}{*}{$\begin{array}{c}\text { 3' UTR residues } \\
64-71\end{array}$} \\
\hline & & & $\begin{array}{c}\text { E protein, residues } \\
154-156 \ddagger\end{array}$ & $\begin{array}{c}\text { NS3, residue } \\
249 \S\end{array}$ & $\begin{array}{c}\text { NS5, residue } \\
653 \pi\end{array}$ & & \\
\hline NY99 & 1999 & Val/Ser & Asn-Tyr-Ser (NYS) & Pro & Phe & Val & Present \\
\hline KUN1960 & 1960 & Ile/Leu & Asn-Tyr-Phe (NYF) & Ala & Ser & lle & Present \\
\hline Boort & 1984 & Ile/Leu & Asn-Tyr-Ser (NYS) & Ala & Phe & lle & Present \\
\hline K2499 & 1984 & Ile/Leu & Asn-Tyr-Ser (NYS) & Ala & Phe & lle & Present \\
\hline K6453 & 1991 & lle/Leu & Asn-Tyr-Ser (NYS) & Ala & Phe & lle & Present \\
\hline Hu6774 & 1991 & Ile/Leu & Asn-Tyr-Ser (NYS) & Ala & Phe & lle & Present \\
\hline Gu0631 & 2000 & Ile/Leu & Asn-Tyr-Ser (NYS) & Ala & Phe & lle & Present \\
\hline Gu1009 & 2000 & Ile/Leu & Asn-Tyr-Ser (NYS) & Ala & Phe & lle & Absent \\
\hline K68967 & 2009 & Ile/Leu & Asn-Tyr-Ser (NYS) & Ala & Phe & Val & Absent \\
\hline P9974 & 2009 & Ile/Leu & Asn-Tyr-Ser (NYS) & Ala & Phe & Val & Absent \\
\hline NSW2011 & 2011 & Ile/Leu & Asn-Tyr-Ser (NYS) & Ala & Phe & Val & Absent \\
\hline K74015 & 2011 & lle/Leu & Asn-Tyr-Ser (NYS) & Ala & Phe & Val & Absent \\
\hline NSW2012 & 2012 & lle/Leu & Asn-Tyr-Ser (NYS) & Ala & Phe & Val & Absent \\
\hline 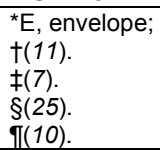 & onstructl & prM, premem & e; UTR, untranslated res & & & & \\
\hline
\end{tabular}

\section{Growth Kinetics and Plaque Morphology of WNV $_{\text {KuN }}$ Strains}

Infection of Vero cells at $24 \mathrm{~h}$ postinfection demonstrated that $\mathrm{WNV}_{\mathrm{KUN} 1960}, \mathrm{WNV}_{\mathrm{K} 2499}, \mathrm{WNV}_{\mathrm{K} 6453}$, and $\mathrm{WNV}_{\mathrm{K} 68967}$ isolates yielded significantly lower titers than did $\mathrm{WNV}_{\mathrm{NY} 99}$ $(\mathrm{p}<0.05)$ (Figure 1 , panel A). However, by $48 \mathrm{~h}$ postinfection, similar titers were reached for all WNV isolates except $\mathrm{WNV}_{\text {KUN1960 }}$.

A similar trend was observed in $\mathrm{C} 6 / 36$ cells, in which viral titers of $\mathrm{WNV}_{\mathrm{KUN1960}}, \mathrm{WNV}_{\mathrm{K} 2499}, \mathrm{WNV}_{\mathrm{K} 68967}$, and $\mathrm{WNV}_{\mathrm{GU} 1009}$ were significantly lower than those for $\mathrm{WNV}_{\mathrm{NY} 99}, \mathrm{WNV}_{\mathrm{NSW} 2011}$, and $\mathrm{WNV}_{\text {Boort }}$ at $48 \mathrm{~h}$ after infection $(\mathrm{p}<0.05)$ and titers for $\mathrm{WNV}_{\mathrm{K} 6453}, \mathrm{WNV}_{\mathrm{K} 74015}$, and $\mathrm{WNV}_{\mathrm{GU} 0631}$ were intermediate. By $96 \mathrm{~h}$ after infection, the titers of all $\mathrm{WNV}$ isolates except $\mathrm{WNV}_{\mathrm{KUN} 1960}$ were similar.

In terms of plaque morphology of $\mathrm{WNV}_{\mathrm{KUN}}$ strains, in Vero cells, $\mathrm{WNV}_{\mathrm{NSW} 2011}$ and $\mathrm{WNV}_{\mathrm{K} 74015}$ produced large plaques (average size $4.3 \pm 0.63$ and $4.3 \pm 0.77 \mathrm{~mm}$, respectively), a size similar to those produced by the $\mathrm{WNV}_{\mathrm{NY} 99}$ strain (average size $4.8 \pm 0.45 \mathrm{~mm}$ ). The prototype virus, $\mathrm{WNV}_{\mathrm{KUN} 1960}$, produced very small plaques (average size
$2.7 \pm 0.47 \mathrm{~mm}$ ), which differed significantly from those of all other viruses tested during this study $(p<0.0001)$. The remaining isolates produced intermediate-sized plaques (average size 3.5-3.9 $\pm 0.45-0.84 \mathrm{~mm}$ ) (Figure 2) (5). Plaques formed by $\mathrm{WNV}_{\mathrm{K} 6453}, \mathrm{WNV}_{\mathrm{K} 74015}, \mathrm{WNV}_{\mathrm{Gu} 1009}$, and $\mathrm{WNV}_{\text {Gu0631 }}$ were less well defined than those formed by $\mathrm{WNV}_{\mathrm{NY} 99}^{\mathrm{Gu} 0631}, \mathrm{WNV}_{\mathrm{NSW} 2011}, \mathrm{WNV}_{\mathrm{K} 2499}$, and $\mathrm{WNV}_{\text {Boort }}$.

\section{Virulence of WNV $_{\text {KUN }}$ Strains in Mice}

We previously demonstrated that differentiation between virulent and attenuated strains of WNV can be detected in weanling and young adult mice $(3,27)$. In this study, we found that in addition to $\mathrm{WNV}_{\mathrm{NSW2011}}, 3$ other $\mathrm{WNV}_{\mathrm{KUN}}$ isolates $\left(\mathrm{WNV}_{\text {Boort }}, \mathrm{WNV}_{\mathrm{Gu} 0631}, \mathrm{WNV}_{\mathrm{NSW} 2012}\right)$ were neuroinvasive in both mouse models (Figure 3; online Technical Appendix Table 2). The $\mathrm{WNV}_{\text {Boort }}$ strain, obtained from the spinal cord of a symptomatic horse during a small outbreak of equine disease in southeastern Australia in 1984, was neuroinvasive in young adult mice ( $40 \%$ mortality rate at 1,000 PFU); this finding did not statistically differ in this respect from that for $\mathrm{WNV}_{\text {NSW2011 }}(\mathrm{p}=0.3218)$
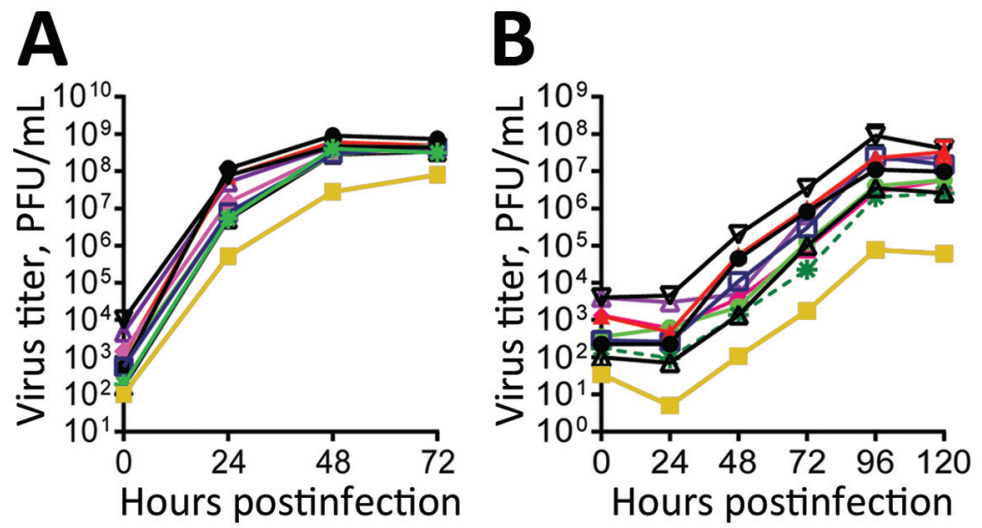

Figure 1. Growth kinetics of West Nile virus strains isolated in Australia, 19602012, in Vero (A) and C6/36 (B) cells. Cells were infected with a multiplicity of infection of 1 , and the virus titers in the supernatants were determined by plaque assay on Vero cells.

$\triangle \mathrm{K} 68967$ (2009)

\pm NSW2011 (2011)

$\triangle$ K74015(2011)

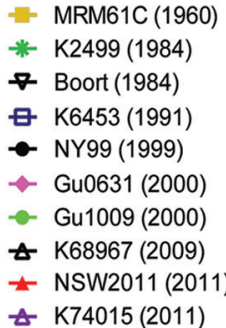



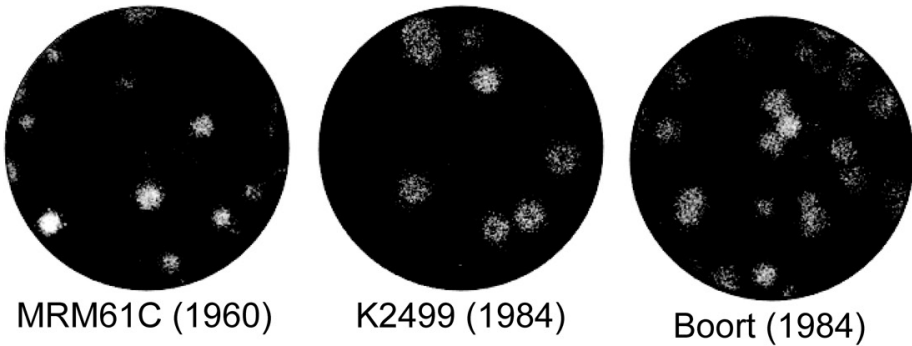

K2499 (1984)
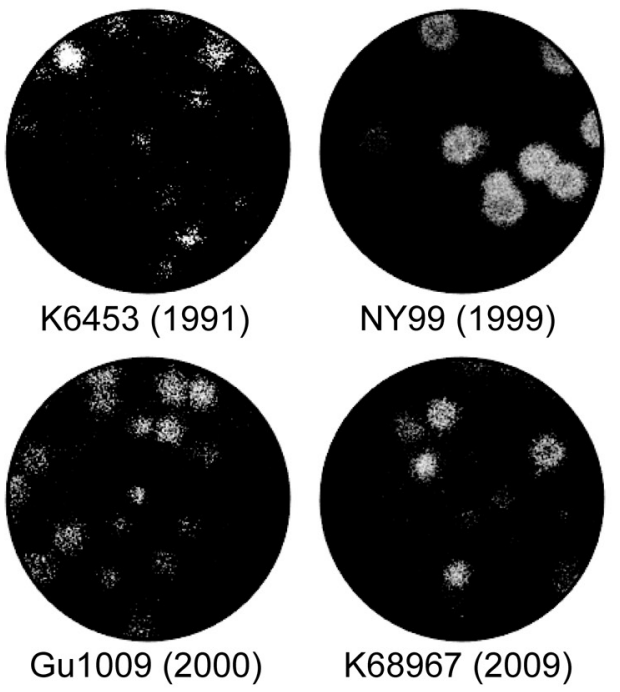

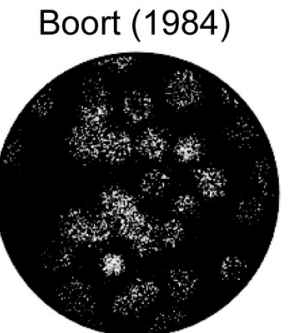

Gu0631 (2000)

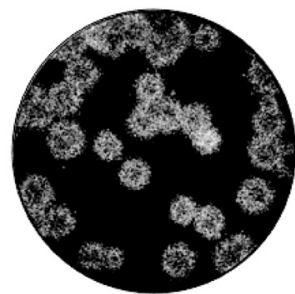

NSW2011 (2011)

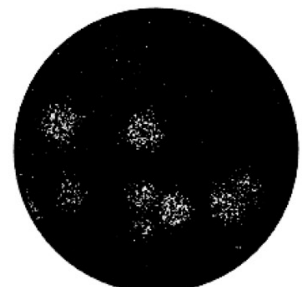

K74015 (2011)
Figure 2. Plaque morphology of representative West Nile virus strains isolated in Australia, 1960-2012. Virus was allowed to adsorb to monolayers of Vero cells for $2 \mathrm{~h}$ at $37^{\circ} \mathrm{C}$. The cells were then overlaid with Dulbecco Modified Eagle Medium containing $0.5 \%$ low melting point agarose and $2 \%$ fetal bovine serum. Four days after infection, the cells were fixed with $4 \%$ formaldehyde solution and stained with $0.2 \%$ crystal violet.
(Figure 3). Two other isolates obtained from mosquitoes, 1 from the Gulf of Carpentaria in $2000\left(\mathrm{WNV}_{\mathrm{Gu} 0631}\right)$ and 1 from southeastern Australia in 2012 ( $\mathrm{WNV}_{\mathrm{NSW} 2012}$ ), also exhibited levels of neuroinvasive properties in young adult mice similar to those caused by $\mathrm{WNV}_{\mathrm{NSW} 2011}$ (Figure 3). In weanling mice, the virulence of $\mathrm{WNV}_{\text {Boort }}, \mathrm{WNV}_{\mathrm{Gu} 0631}$, and $\mathrm{WNV}_{\mathrm{NSW} 2012}$ was also similar to that of $\mathrm{WNV}_{\mathrm{NSW}_{2011}}$; mortality rates, $50 \%$ lethal dose, or time to death did not differ significantly (Table 4). Of note, $\mathrm{WNV}_{\mathrm{Gu} 1009}$ isolated at the same time and from the same region as $\mathrm{WNV}_{\mathrm{GU} 0631}$ was significantly less virulent in young adult mice (Figure 3; online Technical Appendix Table 2). The remaining isolates were relatively attenuated in both young adult (Figure 3 ) and weanling (online Technical Appendix Table 2) mice and did not differ significantly from the attenuated prototype WNV ${ }_{\text {KUN1960 }}$ strain ( $\left.\mathrm{p}>0.05\right)$.

\section{Sequence of Viral Genomes}

We sequenced $\mathrm{WNV}_{\mathrm{KUN}}$ isolates to analyze their relationship to the prototype $\mathrm{WNV}_{\mathrm{KUN}}$ strains from 1960 (WNV MRM16, $\mathrm{WNV}_{\text {MRM61C }}$ ); the 2011 outbreak strains (WNV ${ }_{\mathrm{NSW} 2011}, \mathrm{WNV}_{\mathrm{SA2011}}, \mathrm{WNV}_{\mathrm{V} 11-03}$, and $\left.\mathrm{WNV}_{\mathrm{V} 11-07}\right)$; and exotic strains of WNV known to be virulent in humans and horses $\left(\mathrm{WNV}_{\mathrm{NY} 99}\right)$ or representing different WNV lineages. Phylogenetic analysis of the ORF sequences demonstrated that the $\mathrm{WNV}_{\mathrm{KUN}}$ strains form a single genetically homogeneous clade within lineage 1 (Figure 4), as previously recognized (24); nucleotide and amino acid identities between strains were $96.1 \%-99.4 \%$ and $98.5 \%-100 \%$, respectively. As expected, the most recent isolates, including the 2011 outbreak strain, were the most divergent, and the early prototype strains $\left(\mathrm{WNV}_{\text {MRM61C }}\right.$ and $\mathrm{WNV}_{\text {MRM16 }}$ ) occupied the basal lineage of this clade. Recent strains isolated in 2011 and 2012 from southeastern Australian states clustered together and shared high levels of nucleotide (98.6\%-100\%) and amino acid (99.6\%-100\%) identities, indicating transmission of a genetically homogeneous virus population during this period. These strains were either virulent for horses or shown in this study to be virulent in mice (Figure 3; online Technical Appendix Table 2). No other association between phylogenetic relationships and virulence was found; other virulent strains clustered closely and interspersed with the attenuated strains identified in this study. An expanded phylogenetic analysis that used 45 partial E gene sequences (402 nt) and a larger range of reference $\mathrm{WNV}_{\mathrm{KUN}}$ strains showed a similar pattern of relationships (online Technical Appendix Figure).

Of note is the very close relationship (99.9\% aa identity) between a virulent 2011 strain isolated from a horse and an isolate obtained from Culex annulirostris mosquitoes trapped in New South Wales, Australia, in 2012 $\left(\mathrm{WNV}_{\mathrm{NSW} 2012}\right)$. Only 3 nonconservative changes were identified between $\mathrm{WNV}_{\mathrm{NSW} 2011}$ and $\mathrm{WNV}_{\mathrm{NSW} 2012}$, located in NS1 (Lys33Arg), NS3 (Phe509Leu), and NS4A 


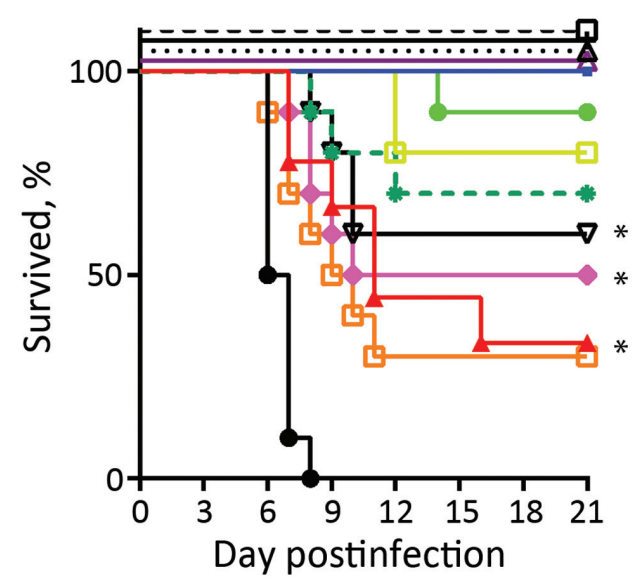

Figure 3. Survival curves for young adult (28-day-old) Swiss outbred mice after intraperitoneal infection with 1,000 PFU of West Nile virus (WNV) strains isolated in Australia, 1960-2012. Groups of 10 mice were infected with each virus. The mice were monitored for 21 days after infection for signs of encephalitis and then euthanized. WNV $\mathrm{NY}_{99}$ and $\mathrm{WNV}_{\text {NSW2011 }}$ with previously demonstrated virulence were included as controls. The significance of clinical differences between groups was calculated by Kaplan-Meier analysis and analyzed by log-rank test. Significantly increased virulence over that of $\mathrm{WNV}_{\text {KUN1960 }}$ is indicated by an asterisk

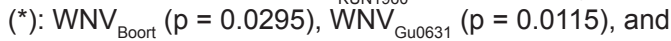
$W N V_{N S W 2012}(p=0.0011)$. No significant differences were observed between $\mathrm{WNV}_{\text {Boort }}, \mathrm{WNV}_{\text {Gu0631 }}$, and $\mathrm{WNV}_{\mathrm{NSW} 2012}$ compared with $\mathrm{WNV}_{\text {NSW2011 }}(\mathrm{p}>0.05)$.
(Phe92Leu). These results suggest that the virulent strain either had persisted in New South Wales after the end of the 2011 outbreak or had been reintroduced to the area.

Analyses of predicted gene products from the complete ORF sequence of each $\mathrm{WNV}_{\mathrm{KUN}}$ isolate revealed that, in addition to the glycosylation site at residues 154-156 in the E protein, all strains isolated after 1960 contained a Phe residue at position 653 in the NS5 protein, which has previously been shown to play a role in resistance to antiviral activity of interferon- $\alpha / \beta(10)$ (Table 3 ). In contrast, $\mathrm{WNV}_{\mathrm{KUN} 1960}$ contained a Ser residue at position 653 in NS5 $(3,5,24,28)$. The Pro residue at position 249 in the NS3 protein, previously shown to be present in WNV strains and associated with increased virulence in birds of some species (25), was not present in any of the $\mathrm{WNV}_{\mathrm{KUN}}$ isolates, which all contained an Ala residue at this position (Table 3).

In addition to an Ile $\rightarrow$ Val substitution at position 49 in NS5 of $\mathrm{WNV}_{\mathrm{KUN}}$ isolates collected after 2009, analysis of more contemporary $\mathrm{WNV}_{\mathrm{KUN}}$ isolates also revealed a consistent 8-nt deletion in the $3^{\prime}$ UTR, just downstream from the ORF stop codon. This deletion was identified in $\mathrm{WNV}_{\mathrm{Gu} 1009}$ and all isolates collected after 2000. In contrast, this deletion was not present in isolates collected before 2000 (Table 3) or in another isolate from Gulf of Carpentaria collected in $2000\left(\mathrm{WNV}_{\mathrm{Gu} 0631}\right)$. We suggest that these 2 features (Ile $\rightarrow$ Val 49 residue in NS5 and an 8 -nt deletion in the $3^{\prime}$ UTR) can be considered as potential evolutionary markers.

In addition to the genetic variability described above, sequence analysis between virulent and attenuated $\mathrm{WN}$ $\mathrm{V}_{\mathrm{KUN}}$ strains identified other nucleotide differences between isolates, located throughout the viral genome. These differences result in amino acid substitutions (Table 4) and may contribute to observed phenotypic differences.

We also sequenced $\mathrm{WNV}_{\mathrm{KUN}}$ viral RNA extracted directly from mosquito saliva expectorated onto sugarsoaked nucleic acid preservation cards placed in mosquito traps in Darwin, Northern Territory, in $2012\left(\mathrm{WNV}_{\mathrm{NT2012}}\right)$
$(29,30)$. When partial sequences from E, NS5, and the $3^{\prime}$ UTR from this RNA were aligned, we observed a high level $(99.7 \%)$ of identity with the $\mathrm{WNV}_{\text {KUN1960 }}$ strains, indicating that viruses genetically homologous to the prototype virus are still circulating in some regions of Australia (online Technical Appendix Figure). Closer analysis revealed a lack of E glycosylation, similar to that found in the prototype strain. However, Phe was identified at position 653 of NS5, similar to that found in recent isolates.

\section{Discussion}

Historically, $\mathrm{WNV}_{\mathrm{KUN}}$ has been associated with only mild disease in humans and rare cases of disease in horses, consistent with data from mouse virulence studies that revealed a relatively attenuated phenotype $(3,8,27)$. Thus, the emergence of an equid-virulent strain of $\mathrm{WNV}_{\mathrm{KUN}}$, responsible for $\approx 900$ cases of encephalitis in horses in southeastern Australia, was unprecedented.

Although most $\mathrm{WNV}_{\mathrm{KUN}}$ isolates examined in this study exhibited an attenuated phenotype, similar to that of the prototype $\mathrm{WNV}_{\mathrm{KUN} 1960}$, we identified an additional 3 strains with neuroinvasive properties in mice similar to those reported for $\mathrm{WNV}_{\mathrm{NSW}_{2011}}(3)$. The first, $\mathrm{WNV}_{\text {Boort }}$, was isolated from the spinal cord of a horse with nonsuppurative encephalomyelitis and severe neurologic symptoms in northern Victoria in 1984 (31). At that time, 53 animals in the same area were clinically affected. However, a high incidence of Ross River virus-specific antibody in these animals implicated that virus rather than $\mathrm{WNV}_{\mathrm{KUN}}$ as the primary etiologic agent (31). Our results are also supported by another recent study showing virulence of $\mathrm{WNV}_{\text {Boort }}$ in 18-19-day-old mice (32).

The second virulent strain identified in this study, $\mathrm{WNV}_{\mathrm{Gu} 0631}$, was isolated from $C x$. annulirostris mosquitoes collected from Normanton, Gulf of Carpentaria, in April 2000. Of note, this virus was isolated in the absence of any reported disease outbreak, as part of a survey for the presence of Japanese encephalitis virus in northern Queensland 
Table 4. Comparison of amino acid sequences between virulent and attenuated West Nile virus strains*

\begin{tabular}{|c|c|c|c|c|c|c|c|c|c|}
\hline \multirow{2}{*}{$\begin{array}{l}\text { Gene and amino acid } \\
\text { position in polyprotein } \\
\text { (corresponding protein) }\end{array}$} & \multirow[b]{2}{*}{ NY99 } & \multirow{2}{*}{$\begin{array}{c}\text { Virulent strains } \\
\text { Boort, NSW2011, } \\
\text { NSW2012, Gu0631 }\end{array}$} & \multicolumn{7}{|c|}{ Attenuated Kunjin strains } \\
\hline & & & KUN1960 & K68967 & K2499 & K6453 & K74015 & Hu6774 & Gu1009 \\
\hline \multicolumn{10}{|c|}{ 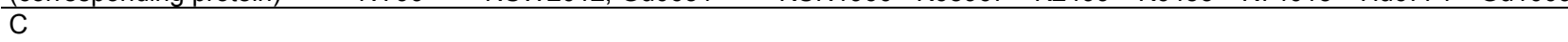 } \\
\hline $86(86)$ & Lys & Lys & Arg & Lys & Lys & Lys & Lys & Lys & Lys \\
\hline $114(114)$ & Met & $\begin{array}{c}\text { Ile (Boort), Thr } \\
\text { (NSW2011, } \\
\text { NSW2012, Gu0631) }\end{array}$ & Met & Thr & Thr & Thr & Met & Thr & Thr \\
\hline \multicolumn{10}{|c|}{ (2) } \\
\hline $143(20)$ & Thr & Ala & Thr & Ala & Ala & Ala & Ala & Ala & Ala \\
\hline $158(35)$ & Ile & Thr & Ile & Thr & Thr & Thr & Thr & Thr & Thr \\
\hline $279(156)$ & Val & Thr & Ala & Thr & Thr & Thr & Thr & Thr & Thr \\
\hline \multicolumn{10}{|l|}{$\mathrm{E}$} \\
\hline $413(123)$ & Thr & Thr & Ala & Thr & Thr & Thr & Thr & Thr & Thr \\
\hline 446 (156) & Ser & Ser & Phe & Ser & Ser & Ser & Ser & Ser & Ser \\
\hline $600(310)$ & Lys & Arg & Thr & Arg & Arg & Arg & Arg & Arg & Arg \\
\hline $773(483)$ & Leu & Phe & Leu & Phe & Phe & Phe & Leu & Phe & Phe \\
\hline $790(500)$ & His & $\mathrm{His}$ & Tyr & $\mathrm{His}$ & $\mathrm{His}$ & $\mathrm{His}$ & $\mathrm{His}$ & $\mathrm{His}$ & $\mathrm{His}$ \\
\hline \multicolumn{10}{|l|}{ NS1 } \\
\hline $1081(290)$ & Ser & Asn & Ser & Asn & Asn & Asn & Ser & Asn & Asn \\
\hline \multicolumn{10}{|l|}{ NS2A } \\
\hline $1255(112)$ & Val & Val & Ala & Val & Val & Val & Val & Val & Val \\
\hline 1272 (129) & Ile & Ile & Met & Ile & Ile & Ile & Ile & Ile & Ile \\
\hline $1366(223)$ & Ile & Ile & Val & Ile & Ile & Ile & Ile & Ile & Ile \\
\hline \multicolumn{10}{|l|}{ NS3 } \\
\hline $1520(146)$ & Lys & Lys & Arg & Lys & Lys & Lys & Lys & Lys & Lys \\
\hline $1970(586)$ & Asn & Ser & Asn & Ser & Ser & Ser & Asn & Ser & Ser \\
\hline \multicolumn{10}{|l|}{ NS4A } \\
\hline $2179(55)$ & Ala & Thr & Ala & Thr & Thr & Thr & Thr & Thr & Ala \\
\hline \multicolumn{10}{|l|}{ NS4B } \\
\hline 2296 (23) & Val & Ile & Thr & Ile & Ile & Ile & Ile & Ile & Ile \\
\hline $2324(51)$ & Val & Phe & Val & Phe & Phe & Phe & Val & Phe & Phe \\
\hline 2368 (95) & Ala & Ser & Ala & Ser & Ser & Ser & Ser & Ser & Ser \\
\hline 2450 (177) & Met & Ile & Met & Ile & Ile & Ile & Ile & Ile & Ile \\
\hline $2518(245)$ & Ile & Ile & Val & Ile & Ile & Ile & Ile & Ile & Ile \\
\hline \multicolumn{10}{|l|}{ NS5 } \\
\hline $2629(101)$ & Arg & Lys & Arg & Lys & Lys & Lys & Arg & Lys & Lys \\
\hline 3088 (560) & Asp & Asn & Asp & Asn & Asn & Asn & Asp & Asn & Asn \\
\hline
\end{tabular}

(33). The second Gulf of Carpentaria isolate, $\mathrm{WNV}_{\text {Gu1009, }}$, was also collected in April 2000, from the town of Karumba, which is $\approx 30 \mathrm{~km}$ from Normanton. However, $\mathrm{WNV}_{\mathrm{GU} 1009}$ is genetically distinct and attenuated to the same degree as the prototype $\mathrm{WNV}_{\mathrm{KUN} 1960}$ in 28-day-old mice (Figure 4). These observations demonstrated that virulent $\mathrm{WNV}_{\mathrm{KUN}}$ strains might co-circulate with attenuated strains in some regions of Australia. Furthermore, the circulation of neuroinvasive strains may often appear in the absence of disease outbreaks. This suggestion is consistent with our finding that $\mathrm{WNV}_{\mathrm{N}}$. sw2012 was genetically almost identical to the $\mathrm{WNV}_{\mathrm{NSW} 2011}$ and exhibited similar levels of neuroinvasiveness in mice. However, no cases of disease in equids were associated with $\mathrm{WNV}_{\mathrm{KUN}}$ infection during the 2012 season $(3,4,34)$. This lack of cases suggests that the persistence of virulent strains in southeastern Australia is not the sole determinant for initiating disease outbreaks and that specific climatic and ecologic conditions, perhaps influencing mosquito populations and viral transmission, are also required.

A similar scenario occurred in North America, where an unusually high number of cases in humans $(5,387)$, most in Texas, USA, were reported in 2012. However, sequence analysis of WNV isolates from 2012 revealed that the strains circulating in Texas were virulent and attenuated, and no specific virulence determinants responsible for the increase in cases could be identified (35). Instead, other factors, including temperature and changes in mosquito or bird populations, were speculated to have contributed to the magnitude of the 2012 outbreak (36).

To identify a phylogenetic association with virulence and to identify potential virulence determinants encoded in the genome of $\mathrm{WNV}_{\mathrm{KUN}}$ strains, we also performed fulllength sequencing of the ORF of several of the viruses studied. Although recent virulent strains were phylogenetically closely related, no other association between phylogenetic grouping and virulence phenotype was found (Figure 4; online Technical Appendix Figure). One notable change in the genome that was clearly associated with the temporal distribution of these viruses was a highly conserved 8-base deletion in the $3^{\prime}$ UTR, just downstream of the ORF stop codon. Isolates from samples collected after 2000 , including the virulent $\mathrm{WNV}_{\mathrm{NSW} 2011}$ and attenuated 


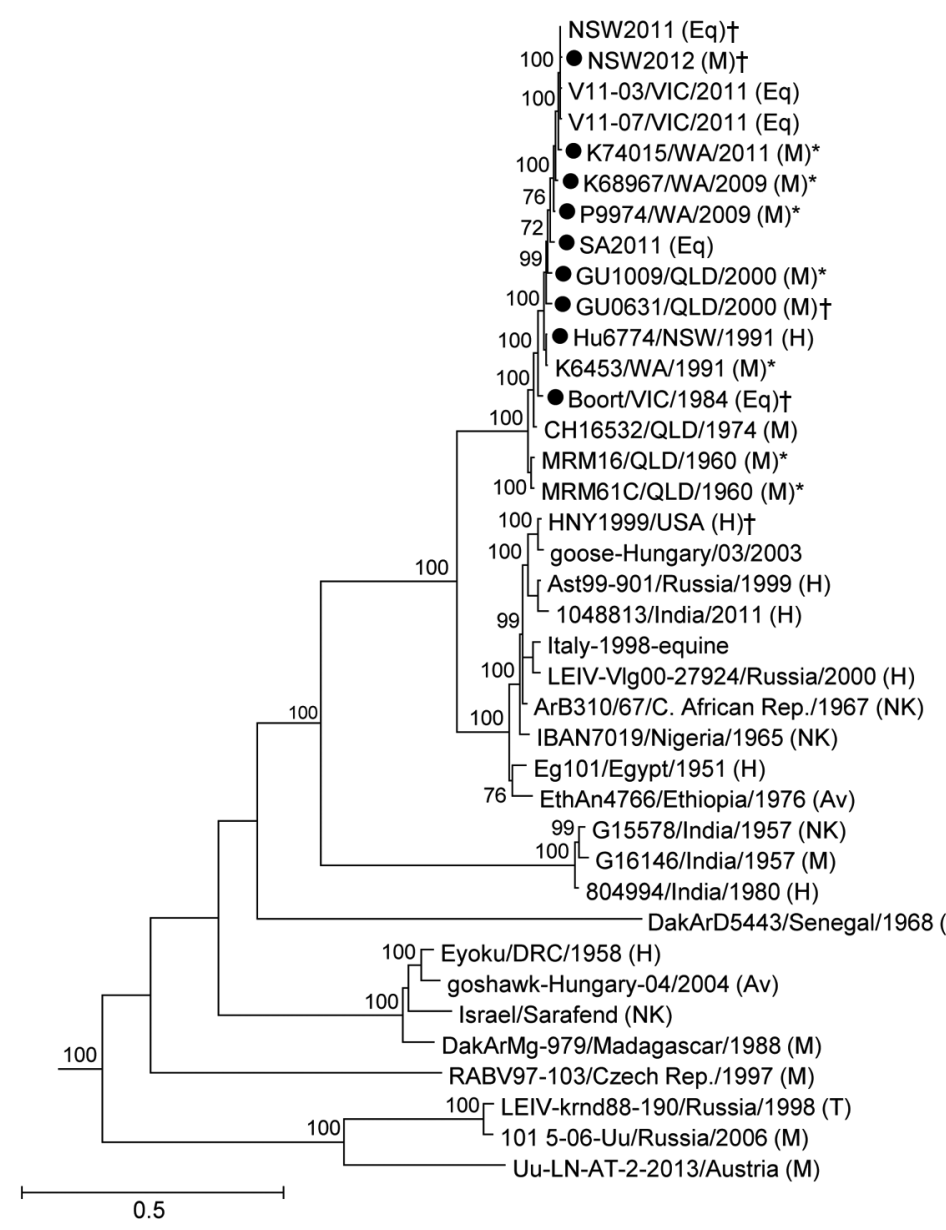

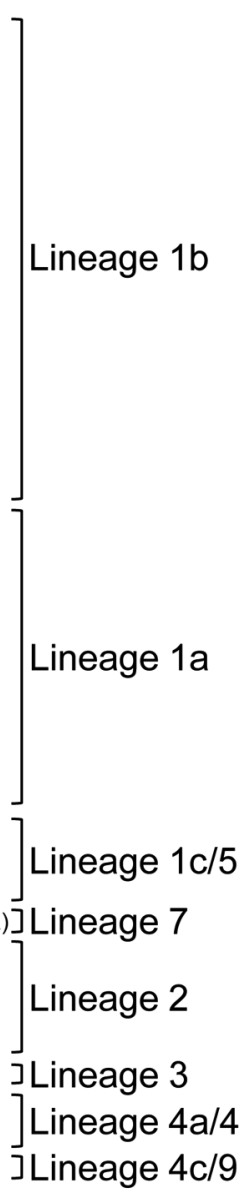

]Lineage $4 c / 9$
Figure 4. Maximum-likelihood phylogenetic tree estimated by using nucleotide sequences of the complete open reading frame (ORF) of genomes of West Nile virus (WNV) strains isolated in Australia, 19602012 (black circles), compared with representative strains from different lineages and clades. The tree was estimated by using a general time-reversible model of nucleotide substitution with a gamma distribution and invariant sites. Bootstrap values are shown on the nodes and are expressed as a percentage of 1,000 replicates; only values $>70 \%$ are shown. Horizontal branch lengths indicate genetic distance. The tree was rooted with the ORF sequences of Murray Valley encephalitis virus and Japanese encephalitis virus; however, these branches have been removed to improve resolution. Strains that were assessed as having an attenuated virulence phenotype are indicated by a single asterisk (*), and virulent strains are indicated by a dagger $(\dagger)$. The state of origin for WNV $_{\text {KUN }}$ strains is shown as follows: NSW, New South Wales; QLD, Queensland; SA, South Australia; VIC, Victoria; WA, Western Australia.

Virus sources are indicated in parentheses next to virus identity, as follows: Av, avian; Eq, equine; $H$, human; M, mosquito; NK, not known; $\mathrm{R}$, rodent; $\mathrm{T}$, tick. Scale bar indicates nucleotide substitutions per site. strains, invariably contained this deletion. This finding suggests that the deletion is an evolutionary marker but is not directly associated with virulence. This finding is also consistent with our observation that the neuroinvasive 2000 Gulf of Carpentaria isolate, $\mathrm{WNV}_{\mathrm{Gu} 0631}$, did not have this deletion but that the co-circulating attenuated isolate, $\mathrm{WNV}_{\text {Gul009, }}$, collected from the same region at the same time, did have this deletion.

An additional evolutionary change was observed in the a-A3 motif of the methyltransferase domain of the NS5 protein. Isolates obtained before 2009, including the prototype $\mathrm{WNV}_{\mathrm{KUN} 1960}$, contained a conserved Ile residue at position 49. However, all isolates collected after 2009 displayed an Ile $\rightarrow$ Val substitution at this position. Coincidentally, this substitution abolished the binding of a mAb $(5 \mathrm{H} 1)$ that recognizes a linear epitope comprising the a-A3 peptide (15).

Initial comparisons between the virulent isolate $\mathrm{WNV}$ from a horse and the attenuated prototype $\mathrm{WNV}_{\mathrm{KUN} 1960}$ revealed that several previously identified WNV virulence markers were detected in the former but not in the latter isolate (3). These markers included the conserved N-linked glycosylation of the E protein (7) and the Phe residue at position 653 in the NS5 protein, associated with resistance to antiviral activity of interferon $\mathrm{a} / \mathrm{b}(8)$. Although these initial observations suggested the involvement of these motifs in the enhanced neuroinvasive properties of the isolate collected from a horse in 2011, our study revealed that, with the exception of $\mathrm{WNV}_{\mathrm{KUN1960}}$, all strains examined contain both of these markers, regardless of virulence phenotype in mouse models. Thus, it seems that, although these motifs contribute to virulence in mice, they are not likely to be solely responsible for enhancing the neuroinvasive properties of some $\mathrm{WNV}_{\mathrm{KUN}}$ strains and, hence, not likely to be markers of evolving virulence in recent isolates of $\mathrm{WNV}_{\mathrm{KUN}}$.

Additional markers of WNV virulence identified in WNV strains from North America were not detected in any of the $\mathrm{WNV}_{\mathrm{KUN}}$ isolates. This finding is consistent with our repeated observations that even the equid-virulent 
$\mathrm{WNV}_{\text {NSW2011 }}$ is substantially less neuroinvasive than $\mathrm{WNV}_{\mathrm{NY} 99}$ in young adult mice (3). These motifs may include Val 22 and Ser 72 residues in the premembrane, which enhance mouse neuroinvasiveness when introduced into the prototype $\mathrm{WNV}_{\mathrm{KUN} 1960}(11)$, and the Pro residue at position 249 in NS3, which is associated with enhanced virulence in birds (25). The absence of the latter motif in all $\mathrm{WNV}_{\mathrm{KUN}}$ strains is also consistent with the perceived lack of illness and death among birds in Australia, notably during the 2011 outbreak among equids. Some isolates included in this study (including $\mathrm{WNV}_{\mathrm{KUN1960}}, \mathrm{WNV}_{\mathrm{SH} 183}, \mathrm{WNV}_{\text {Boort' }}$, and $\left.\mathrm{WNV}_{\text {Hu6774 }}\right)$ have an unknown passage history. Extensive passage through cells is known to occasionally lead to passage-adapted mutations, and care should be taken when interpreting sequencing data from these virus strains.

$\mathrm{WNV}_{\mathrm{KUN}}$ is thought to be endemic to the tropical areas of northern Australia, suggesting that virulent viruses emerging in southeastern Australia probably originate from northern Australia. However, $\mathrm{WNV}_{\mathrm{KUN}}$ recently isolated from mosquitoes in northern Australia, including the 2011 Kimberley isolate $\mathrm{WNV}_{\mathrm{K} 74015}$, were more attenuated than $\mathrm{WNV}_{\text {NSW2011. }}$. This finding suggests a different explanation for the evolution of virulent $\mathrm{WNV}_{\mathrm{KUN}}$ viruses, which may be associated with the adaption of $\mathrm{WNV}_{\mathrm{KUN}}$ to different hosts (avian and terrestrial) or different vector species in temperate regions. In this context, virulence in equids may be just a coincidental outcome of the constraints placed on virus fitness in different geographic locations (35-37).

Overall, our results show that virulent strains of $\mathrm{WNV}_{\mathrm{KUN}}$ have been circulating in Australia for $\geq 30$ years and that the first extensive outbreak of disease among horses in Australia in 2011 probably resulted from a combination of ecologic and epidemiologic conditions rather than the emergence of a novel, more virulent strain. Further studies evaluating viral fitness of West Nile virus quasispecies in terms of population-dependent host-virus interactions, are warranted.

\section{Acknowledgments}

We thank Mary Carr for providing clinical material used for the isolation of $\mathrm{WNV}_{\mathrm{SA}_{2011}}$, Melissa Sanchez and Robert Doms for providing mAb 17D7, and the Western Australian Department of Health for funding and assisting with the detection of $\mathrm{WNV}_{\mathrm{KUN}}$ isolates in Western Australia. We also thank Richard Russell for providing the $\mathrm{WNV}_{\mathrm{NSW} 2012}$ isolate.

This work was supported by the Australian Research Council Linkage Project grant LP120100686 and the National Health and Medical Research Council project grant APP1045188.

Dr. Prow is a postdoctoral research fellow at the QIMR Berghofer Medical Research Institute and is engaged in research to characterize the pathogenesis and virulence of WNV strains in murine models. She also has a special interest in understanding the neuroinvasive properties of neurotrophic flaviviruses.

\section{References}

1. Murgue B, Zeller H, Deubel V. The ecology and epidemiology of West Nile virus in Africa, Europe and Asia. Curr Top Microbiol Immunol. 2002;267:195-221. http://dx.doi.org/10.1007/978-3-64259403-8 10

2. Lanciotti RS, Roehrig JT, Deubel V, Smith J, Parker M, Steele K, et al. Origin of the West Nile virus responsible for an outbreak of encephalitis in the northeastern United States. Science. 1999;286:2333-7. http://dx.doi.org/10.1126/science.286.5448.2333

3. Frost MJ, Zhang J, Edmonds JH, Prow NA, Gu X, Davis R, et al. Characterization of virulent West Nile virus Kunjin strain, Australia, 2011. Emerg Infect Dis. 2012;18:792-800. http://dx.doi.org/10.3201/eid1805.111720

4. Roche SE, Wicks R, Garner MG, East IJ, Paskin R, Moloney BJ, et al. Descriptive overview of the 2011 epidemic of arboviral disease in horses in Australia. Aust Vet J. 2013;91:5-13. http://dx.doi.org/10.1111/avj.12018

5. Adams SC, Broom AK, Sammels LM, Hartnett AC, Howard MJ, Coelen RJ, et al. Glycosylation and antigenic variation among Kunjin virus isolates. Virology. 1995;206:49-56. http://dx.doi.org/10.1016/S0042-6822(95)80018-2

6. Audsley M, Edmonds JH, Liu W, Mokhonov V, Mokhonova E, Melian EB, et al. Virulence determinants between New York 99 and Kunjin strains of West Nile virus. Virology. 2011;414:63-73. http://dx.doi.org/10.1016/j.virol.2011.03.008

7. Beasley DW, Whiteman MC, Zhang S, Huang CY, Schneider BS, Smith DR, et al. Envelope protein glycosylation status influences mouse neuroinvasion phenotype of genetic lineage 1 West Nile virus strains. J Virol. 2005;79:8339-47. http://dx.doi.org/10.1128/ JVI.79.13.8339-8347.2005

8. Daffis S, Lazear HM, Liu WJ, Audsley M, Engle M, Khromykh AA, et al. The naturally attenuated Kunjin strain of West Nile virus shows enhanced sensitivity to the host type I interferon response. J Virol. 2011;85:5664-8.

9. Keller BC, Fredericksen BL, Samuel MA, Mock RE, Mason PW, Diamond MS, et al. Resistance to alpha/beta interferon is a determinant of West Nile virus replication fitness and virulence. J Virol. 2006;80:9424-34. http://dx.doi.org/10.1128/ JVI.00768-06

10. Laurent-Rolle M, Boer EF, Lubick KJ, Wolfinbarger JB, Carmody AB, Rockx B, et al. The NS5 protein of the virulent West Nile virus NY99 strain is a potent antagonist of type I interferon-mediated JAK-STAT signaling. J Virol. 2010;84:350315. http://dx.doi.org/10.1128/JVI.01161-09

11. Setoh YX, Prow NA, Hobson-Peters J, Lobigs M, Young PR, Khromykh AA, et al. Identification of residues in West Nile virus pre-membrane protein that influence viral particle secretion and virulence. J Gen Virol. 2012;93:1965-75. http://dx.doi.org/10.1099/ vir.0.044453-0

12. Doherty RL, Carley JG. Studies of arthropod-borne virus infections in Queensland. II. Serological investigations of antibodies to dengue and Murray Valley encephalitis in eastern Queensland. Aust J Exp Biol Med Sci. 1960;38:427-39. http://dx.doi.org/10.1038/ icb. 1960.46

13. Khromykh AA, Kenney MT, Westaway EG. Transcomplementation of flavivirus RNA polymerase gene NS5 by using Kunjin virus replicon-expressing BHK cells. J Virol. 1998;72:7270-9.

14. Westaway EG. Assessment and application of a cell line from pig kidney for plaque assay and neutralization tests with twelve group B arboviruses. Am J Epidemiol. 1966;84:439-56.

15. Hall RA, Tan SE, Selisko B, Slade R, Hobson-Peters J, Canard B, et al. Monoclonal antibodies to the West Nile virus NS5 protein map to linear and conformational epitopes in the methyltransferase and polymerase domains. J Gen Virol. 2009;90:2912-22. http://dx.doi.org/10.1099/vir.0.013805-0 
16. Wang GP, Bushman FD. A statistical method for comparing viral growth curves. J Virol Methods. 2006;135:118-23. http://dx.doi.org/10.1016/j.jviromet.2006.02.008

17. Warrilow D, Hall-Mendelin S, Hobson-Peters J, Prow NA, Allcock R, Hall RA. Complete coding sequences of three members of the Kokobera group of flaviviruses. Genome Announc. 2014; 2:pii:e00890-14. http://dx.doi.org/10.1128/genomeA.00890-14

18. Palacios G, Quan PL, Jabado OJ, Conlan S, Hirschberg DL, Liu Y, et al. Panmicrobial oligonucleotide array for diagnosis of infectious diseases. Emerg Infect Dis. 2007;13:73-81. http://dx.doi.org/10.3201/eid1301.060837

19. Tamura K, Stecher G, Peterson D, Filipski A, Kumar S. MEGA6: Molecular Evolutionary Genetics Analysis version 6.0. Mol Biol Evol. 2013;30:2725-9. http://dx.doi.org/10.1093/molbev/mst197

20. Guindon S, Gascuel O. A simple, fast, and accurate algorithm to estimate large phylogenies by maximum likelihood. Syst Biol. 2003;52:696-704. http://dx.doi.org/10.1080/10635150390235520

21. Darriba D, Taboada GL, Doallo R, Posada D. jModelTest 2: more models, new heuristics and parallel computing. Nat Methods. 2012;9:772. http://dx.doi.org/10.1038/nmeth.2109

22. Hall RA, Kay BH, Burgess GW, Clancy P, Fanning ID. Epitope analysis of the envelope and non-structural glycoproteins of Murray Valley encephalitis virus. J Gen Virol. 1990;71:2923-30. http://dx.doi.org/10.1099/0022-1317-71-12-2923

23. Hobson-Peters J, Toye P, Sanchez MD, Bossart KN, Wang LF, Clark DC, et al. A glycosylated peptide in the West Nile virus envelope protein is immunogenic during equine infection. J Gen Virol. 2008;89:3063-72. http://dx.doi.org/10.1099/vir.0.2008/003731-0

24. Scherret JH, Poidinger M, Mackenzie JS, Broom AK, Deubel V, Lipkin WI, et al. The relationships between West Nile and Kunjin viruses. Emerg Infect Dis. 2001;7:697-705. http://dx.doi.org/10.3201/eid0704.017418

25. Brault AC, Huang CY, Langevin SA, Kinney RM, Bowen RA, Ramey WN, et al. A single positively selected West Nile viral mutation confers increased virogenesis in American crows. Nat Genet. 2007;39:1162-6. http://dx.doi.org/10.1038/ng2097

26. Tan CS, Hobson-Peters JM, Stoermer MJ, Fairlie DP, Khromykh AA, Hall RA. An interaction between the methyltransferase and RNA dependent RNA polymerase domains of the West Nile virus NS5 protein. J Gen Virol. 2013;94:1961-71. http://dx.doi.org/10.1099/vir.0.054395-0

27. Prow NA, Setoh YX, Biron RM, Sester DP, Kim KS, Hobson-Peters J, et al. The West Nile virus-like flavivirus Koutango is highly virulent in mice due to delayed viral clearance and the induction of a poor neutralizing antibody response. J Virol. 2014;88:9947-62. http://dx.doi.org/10.1128/JVI.01304-14
28. Wright PJ, Warr HM, Westaway EG. Synthesis of glycoproteins in cells infected by the flavivirus Kunjin. Virology. 1981;109:418-27. http://dx.doi.org/10.1016/0042-6822(81)90512-2

29. Hall-Mendelin S, Ritchie SA, Johansen CA, Zborowski P, Cortis G, Dandridge S, et al. Exploiting mosquito sugar feeding to detect mosquito-borne pathogens. Proc Natl Acad Sci U S A. 2010;107:11255-9. http://dx.doi.org/10.1073/ pnas. 1002040107

30. van den Hurk AF, Hall-Mendelin S, Townsend M, Kurucz N, Edwards J, Ehlers G, et al. Applications of a sugar-based surveillance system to track arboviruses in wild mosquito populations. Vector Borne Zoonotic Dis. 2014;14:66-73. http://dx.doi.org/10.1089/vbz.2013.1373

31. Badman R, Campbell J, Aldred J. Arbovirus infection in horsesVictoria. Commun Dis Intell. 1984;17:5-6.

32. Bingham J, Payne J, Harper J, Frazer L, Eastwood S, Wilson S, et al. Evaluation of a mouse model for the West Nile virus group for the purpose of determining viral pathotypes. J Gen Virol. 2014;95:1221-32. http://dx.doi.org/10.1099/vir.0.063537-0

33. van den Hurk AF, Nisbet DJ, Foley PN, Ritchie SA, Mackenzie JS, Beebe NW. Isolation of arboviruses from mosquitoes (Diptera: Culicidae) collected from the Gulf Plains region of northwest Queensland, Australia. J Med Entomol. 2002;39:786-92. http://dx.doi.org/10.1603/0022-2585-39.5.786

34. Prow NA. The changing epidemiology of Kunjin virus in Australia. Int J Environ Res Public Health. 2013;10:6255-72. http://dx.doi.org/10.3390/ijerph10126255

35. Coffey LL, Forrester N, Tsetsarkin K, Vasilakis N, Weaver SC. Factors shaping the adaptive landscape for arboviruses: implications for the emergence of disease. Future Microbiol. 2013;8:155-76. http://dx.doi.org/10.2217/fmb.12.139

36. Duggal NK, D'Anton M, Xiang J, Seiferth R, Day J, Nasci R, et al. Sequence analyses of 2012 West Nile virus isolates from Texas fail to associate viral genetic factors with outbreak magnitude. Am J Trop Med Hyg. 2013;89:205-10. http://dx.doi.org/10.4269/ajtmh.13-0140

37. van den Hurk AF, Hall-Mendelin S, Webb CE, Tan CS, Frentiu FD, Prow NA, et al. Role of enhanced vector transmission of a new West Nile virus strain in an outbreak of equine disease in Australia in 2011. Parasites \& Vectors. 2014;7:586. http://dx.doi.org/10.1186/ s13071-014-0586-3

Address for correspondence: Roy A. Hall or Alexander A. Khromykh, The University of Queensland, St. Lucia, 4072, Queensland, Australia; email: roy.hall@uq.edu.au or a.khromykh@uq.edu.au

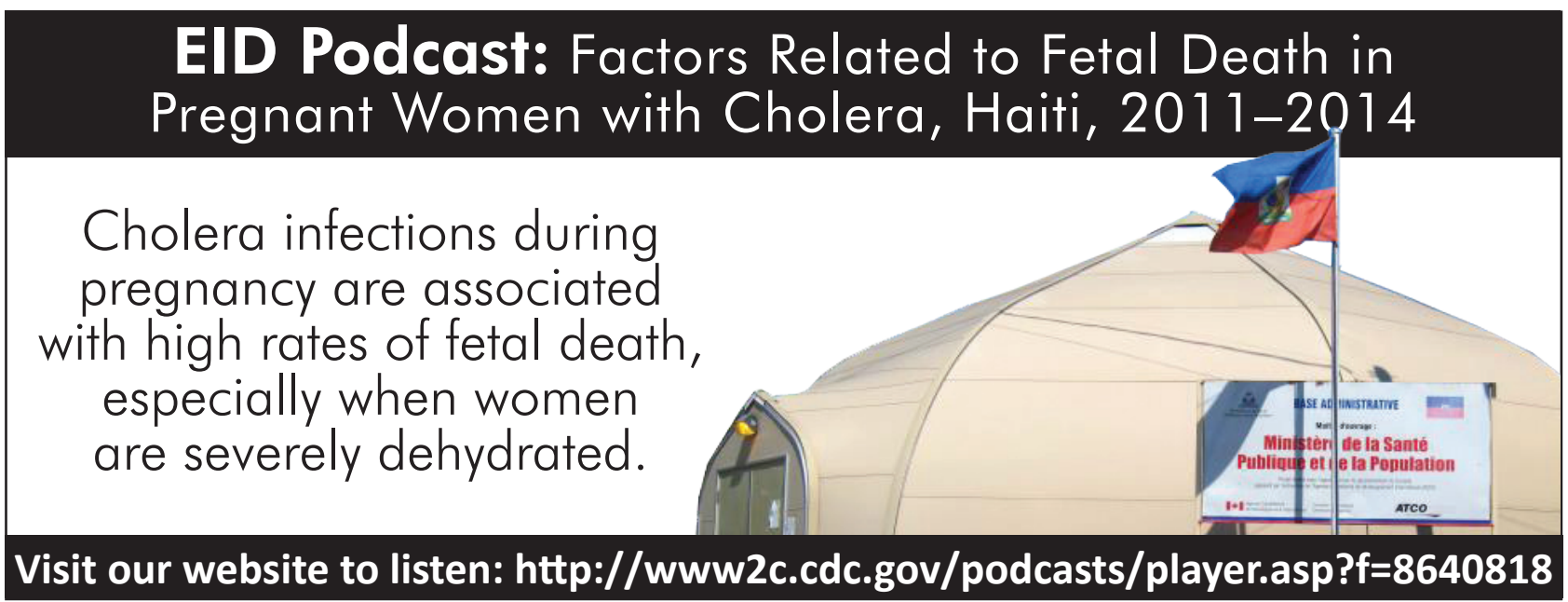

